(C) 1988 ISIJ

\section{樹脂射出成形解析の最近の進歩}

\author{
裕之*2
}

\section{解 説}

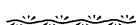

\title{
Recent Progress of Analytical Technique about Injection Molding
} Processes

Takashi ICHIYANAGI and Hiroyuki NAKA

\section{1.は じめに}

樹脂成形法の中の代表的プロセスの一つに，射出成形 法があげられる．射出成形法の各工程を大別すると, 溶 融樹脂を金型内に射出注入する充填工程，冷却に伴う熱 収縮を見込んで過圧縮する保圧工程, 及び金型自身の持 つ大きい熱容量を利用して成形品を冷却する冷却工程に 分けられる. 以上の各工程を巧みに制御して，表面及び 形状精度の優れた成形品を効率的に生産する金型設計の 努力が続けられてきた。例えば，手持ちの成形機の射出 能力を越える成形压を必要とする金型の改造・設計変更 や, 複数の樹脂流の合流部に生じるウェルド位置の予測 とコントロール, 金型内への樹脂流入口であるゲートの 点数とその配置, 成形サイクル短縮化を図る効率的金型 温調回路設計等に, 金型技術者の長年の経験と勘が必要 とされてきた.

しかしながら, 近年来のコンピューターの発達と併せ て, OA 機器を主体とする家電・自動車部品等の新たな 需要構造の変革の中で, 高精度 - 高品質 - 高効率の射出 成形が強く求められるようになつた。これを受けて，金 型内の樹脂流れや温度履歴等を解析シミュレーションす ることによつて具現化し，より正確な情報を得ようとす る取組が 10 数年前から盛んに行われるようになり, 現 在その研究の一部は, 実際の金型設計へ適用され, 多く の効果をあげるに至つている.

本稿では, 射出成形にまつわる種々の研究に注目し, その取組内容及び成果について紹介し, 併せて将来技術 の展望を行いたいと考える.

\section{2. 材料評価技術}

樹脂射出成形工程にまつわる種々の現象を解明しよう とするとき, 樹脂特有の材料物性を正確に把握する必要 がある、まず，流動解析を行うときに不可欠となる非

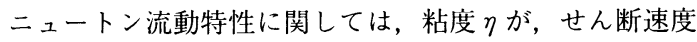
文のべき乗に比例するという, べき乗則を基本とし，こ れに温度依存項を考慮するのが通常である ${ }^{1)}$. その一般 形は式( 1 )に表現される。

$$
\eta=C \dot{\gamma}^{n-1} \exp \left(T_{a} / T\right)
$$

ここで $C, n, T_{a}$ が樹脂固有の材料定数で, $T$ は任意の 樹脂温度を示す。また， $B, T, C, n$ の 4 定数を用いた モデルとして,

$$
\begin{aligned}
& \eta=\frac{\eta_{0}(T)}{1+C\left(\eta_{0} \dot{\gamma}\right)^{1-n}} \cdots \cdots \\
& \eta_{0}(T)=B \exp \left(T_{b} / T\right)
\end{aligned}
$$

も提唱されている2). 式( 1 )の中の材料定数を求めるた めの手法も種々提案されているが, 図 1 に示すように, 一定温度で溶融させた樹脂を円筒状または矩形状のノズ ルから流出させ, その時の温度・圧力を測定することか らモデル化した関係式を用いて $\eta \boldsymbol{v s} \dot{\gamma}$ 曲線を得る手法

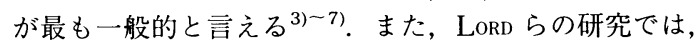
ポリカーボネート樹脂に関して, 粘度の圧力依存性が陽 に作用することが確認され, 圧力依存項の考慮により流 動解析精度が向上したとの報告8) も見られる（図 2 参 照).しかし，ここで用いられる材料特性評価手法のモ

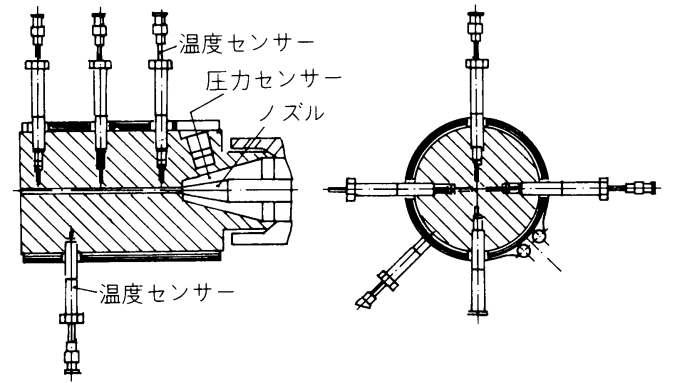

図 1 樹脂粘度特性の代表的測定例 昭和 62 年 8 月 3 日受付 (Received Aug. 3, 1987) (依頼解説)

* 松下電器産業(株)生産技術本部 副参事 (Production Engineering Lab., Matsushita Electric Ind. Co. LTD., 2-7 Matsuba-cho Kadoma Osaka 571)

*2 松下電器産業 (株)生産技術本部 技師（Production Engineering Lab., Matsushita Electric Ind. Co. LTD.) Key words : plastics ; injection molding; dimentional accuracy ; metall mold ; flow analysis ; simulation ; mathematical model ; optimization ; reinforced plastics ; defect. 


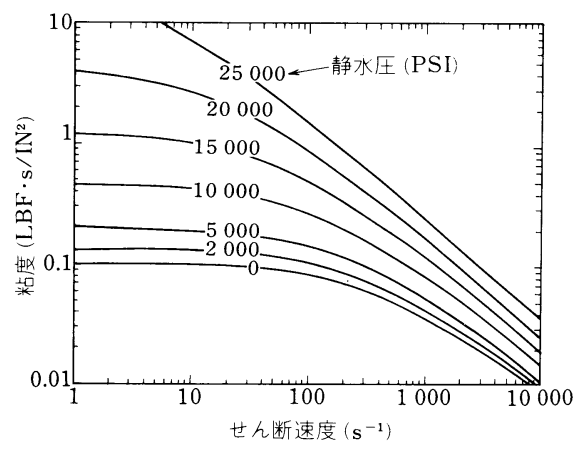

図 2 せん断速度対粘度の圧力依存効果 (ポリカー ボネート)

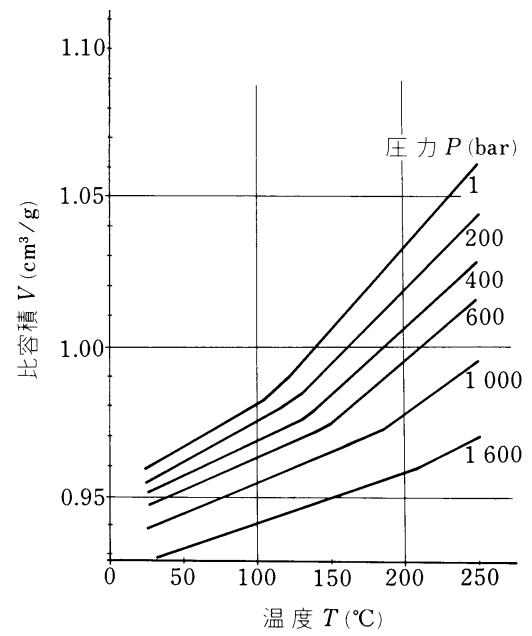

図 $3 P-V-T$ 特性曲線の例（ABS 樹脂）

デルは，実際の金型における樹脂温度や流動状態と厳密 には異なつており，以上をふまえた評価技術の確立が課 題として残されている.

一方, 充填後の保圧, 冷却収縮・ひけ, 反り等の現象 を考察するとき, 樹脂の压縮特性の把握が不可欠となる. 樹脂の圧縮性に関しては, SPENCER, GILMORE $5^{910)}$ が式 (4)に示す状態方程式を提示して以来, 種々の樹脂への 適用が研究されている ${ }^{9)-18)}$.

$$
\left(P+\pi_{i}\right)(v-w)=R_{m}(T+273)
$$

ここで $P, v, T$ は, おのおの圧力, 体積, 温度を指し, $\pi_{i}, w, R_{m}$ は材料に依存する定数である. 特に MAXWELL $ら^{11)}$ は, 樹脂の圧縮性が加圧速度に依存し得ることを 示し, 山口・大柳ら ${ }^{12)}$ は静水圧効果に関する研究も行 つている。また，種々の実験デー夕を体系的にまとめ上 げた総合デー夕資料 ${ }^{13)}$ も見うけられる (図 3 参照).た だし，これらのデー夕は，最大圧力が拈㧍むね，高々 1500 2 $000 \mathrm{kgf} / \mathrm{cm}^{2}$ 程度に限られており，これを超え
る圧力領域に対する特性に関しては，実験の困難さもあ いまつて，いまだデータが十分そろつていない状況にあ る. 従つて, 射出圧縮成形等の高圧成形を取り扱う解析 においては，まず樹脂の高圧条件特性から把握する必要 がある。

\section{3. 充填工程解析}

金型内の樹脂流動挙動を正確にシミュレーションする ことにより，樹脂流れを適正化し，合理的金型設計に反 映させようという試みから流動解析の研究が始められ た. 現在，樹脂射出成形の全工程の中で最も解析技術的 に完成度が高い分野であり，実際の金型設計に適用され 種々の効果を発揮している19) -44). 解析においては, 一 般的に成形品形状の肉厚が相対的に薄いことから, Hele-Shaw 流れ ${ }^{19)}$ を仮定し，ニュートン流体に関する 運動方程式，エネルギー保存式と流れの連続条件を考え た基礎式が用いられている.

$$
\begin{aligned}
& -\frac{\partial P}{\partial x}+\eta \frac{\partial^{2} V_{x}}{\partial z^{2}}=0 \\
& -\frac{\partial P}{\partial y}+\eta \frac{\partial^{2} V_{y}}{\partial z^{2}}=0 \\
& \rho C_{P}\left(\frac{\partial T}{\partial t}+V_{x} \frac{\partial T}{\partial x}+V_{y} \frac{\partial T}{\partial y}\right)=K \frac{\partial^{2} T}{\partial z^{2}}+\eta \dot{\gamma}^{2}
\end{aligned}
$$

$$
\frac{\partial V_{x}}{\partial x}+\frac{\partial V_{y}}{\partial y}=0
$$

ここで, $\boldsymbol{z}$ を肉厚方向とし，これに直交する $\boldsymbol{x}-\boldsymbol{y}$ 平面で の流速を $V_{x}, V_{y}$ とする。 また $\rho, C_{P}, K$ はおのおの樹 脂の密度, 比熱, 熱伝導率である. 樹脂粘度の材料非線 形性については，計算過程で刻々更新される速度場に基 づいて修正することにより考慮される．流動解析で特徴 的な点は, 式 $(7)$ で示すエネルギー方程式である. 流速 に乗つて運ばれる熱移流項を除くと，熱伝導に関しては 金型壁への放熱のみを考える。これは成形時の Fountain effect (噴水効果) を盛り込んだ仮定である. Fountain effect は，ゲート部から供給される溶融樹脂が壁と 接触する部分でのみ固化し，その他は次々に流れの先端 へ送り出されて停流しない性質を指して言う。その自由 表面の流動挙動に関して GoGos $5^{45)}$ ，KAMAL $5^{46)}$ が MAC 法を用いた解析を，また MAVRIDIS ら ${ }^{47)}$ が有限要 素法を用いた解析を行つている(図 4,5参照).

また，特に成形品肉厚が薄く，射出速度が大きい成形 条件下では, せん断発熱が無視できなくなるため,式( 7 ) 右辺第 2 項を入れる場合が多い. 以上式( 5 ) （8)から 解を導く方法として, W ANG, HIEBER らの提唱する有限 要素法の概念を用いた解法 ${ }^{2)}$ と， TADMOR らが提唱する FAN 法 (Flow Analysis Network Method) ${ }^{31)}$ とに大別 される．以下にこれらの解析手法を用いて実際の金型設 計へ適用された事例を紹介する. 
ウェルド位置予測を目的として，コンピューターキー ボード39) (図 6 参照) やスピーカーボックスに，成形品 肉厚の最適化を目的としてヒーター部品に，ランナーバ ランスを目的としてコネクターのファミリー成形 ${ }^{40)} に$, その他ゲート位置の最適化とゲート点数削減を目的とし て, 掃除機天板 (図 7 参照), エアコン, テレビキャビネッ

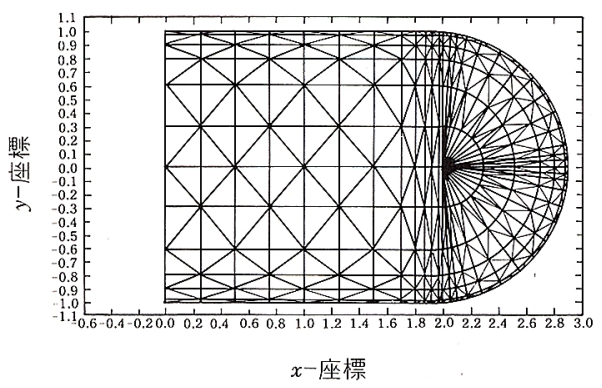

図 4 平行平板のメルトフロント部の有限要素メッ シュ切り

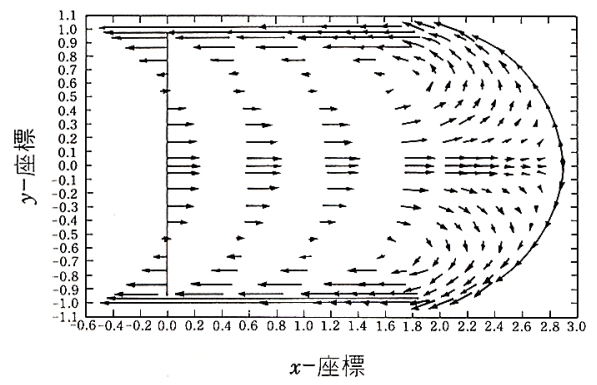

図 5 平行平板のメルトフロント部の樹脂流れ解析 結果

ト，ビデオテープカセット等に適用されている。これほ の解析結果は，ショートショットした検証実験から得巨 れるフローパターンと良い一致を示す2)(図 8 参照)に か，先に述べた粘度評洒式を正確に評価することで，成 形圧力值に関しても，誤差 $\pm 10 \%$ 以内程度に抑えられ ることが確認されている。また，純理論の見地を離れて， 実用を主眼とした図式解法 ${ }^{48)}$ 〜51) ，経験則に基づく データベースを主体とした, 独自の流動解析ソフト ${ }^{37}$ も実用に供されている．更に，樹脂流動現象を詳細に解 析しようとする試みも種々行われ，薄肉キャビティ解杖 における境界条件の与え方に関して KAMAL ら ${ }^{52)}$ ，KRUE GER $5^{53)}$ ，RYAN $5^{54)}$ の研究，矩形キャビティにおけそ メルトフロント位置と上流. 下流流れとの相関性に関す
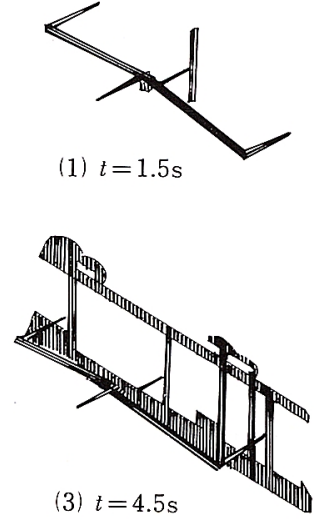

(3) $t=4.5 \mathrm{~s}$

図 6 解析で求められたコンピューターキーボード の充壃パターン

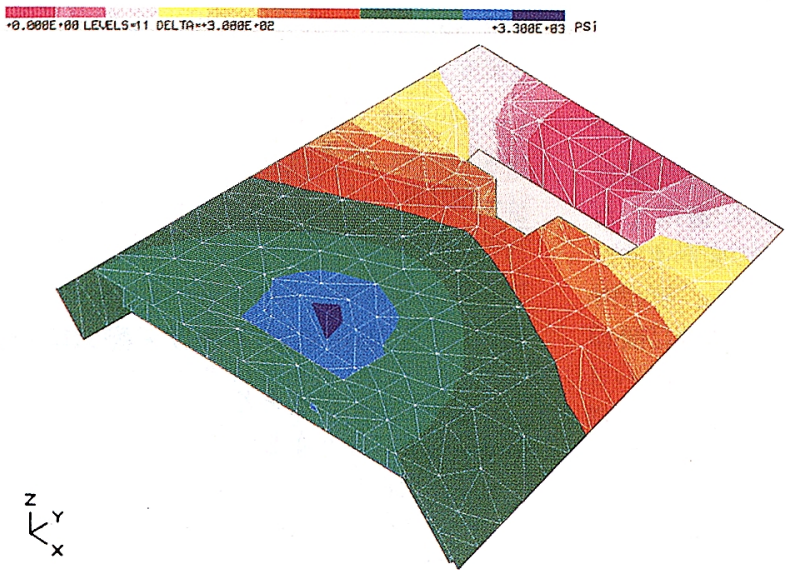

図 7 掃除機天板パネルの 充填解析結果 (圧力分布) 
(a)

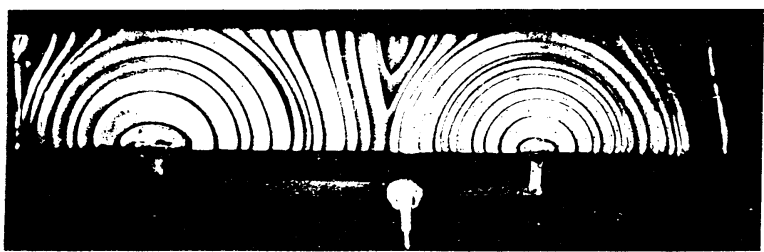

(b)

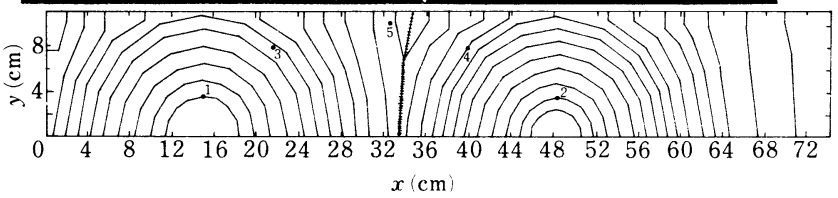

(a) 奏際の金型内樹脂流のショートショットパターン

(b) 允填解析によるメルトフロントの進展状況

図 8 解析精度の検証。

る SOH $5^{55)}$ の研究, 結晶ポリマーの凝固潜熱を考慮し た流動モデルに関する藤井ら ${ }^{56)}$ の研究, 結晶性ポリマー の平行キャビティ内の固相発達にステファン解を用いた 近似計算例 ${ }^{57)}$, 注入ポリマー先端と共に動く座標系に 物理モデルを適用した研究例 ${ }^{58)}$ 等が見られる.

一方, 現行の樹脂流動解析における最大の問題点は, その温度分布計算結果が信賴性に乏しい点にある。原因 として, 先述の式 $(7)$ の記述に厳密性が不足しているた めと考えられる. 今後これらの問題に対する取扱い手法 が確立されることで，より正確な流動解析が実現するほ か, 特異な流動挙動として,ヘジテーション, ジェッティ ングや，ガス抜きを考慮した流動解析も実用化されるこ とが期待される.

\section{4. 保圧工程解析}

流動解析が，金型内に樹脂を光填できるか否かを判断 するために用いられるのに対し, 保压工程以降の解析は, 主としてでき上がつた成形品の形状・精度がいかに確保 できるかを最大の関心事とする点で視点を異にする．保 压工程の解析は, 充填工程に比べ研究例が少なく, 今後 の課題も多い. 歴史的には Kamal, KENIG ${ }^{59) 60)}$ がメル トの進展を射出压と型内平均压との差に比例するという 仮定を適用したのが最初で, その後種々の解法や初期・ 境界条件の与え方が検討 ${ }^{61) 62)}$ され, ニュートン流体に Specer-Gilmore 式を適用したディスクキャビティ解析 例 $^{63)}$ も見られる。ここでは，平板解析に適用した $\mathrm{CHUNG}^{64)}$ の例を示す. 保压页.程では, 樹脂の変形速度が 小さいためニュートン流体としての取扱いをし，更に肉 厚方向の速度・压力・密度を平均化した等温流れに関し て以下の連続・運動方程式を用いる.

$$
\begin{aligned}
& \frac{\partial \rho}{\partial t}+\frac{\partial}{\partial x} \rho \bar{U}+\frac{\partial}{\partial y} \rho \bar{V}=0 \\
& \frac{\partial P}{\partial x}=\eta \frac{\partial^{2} U}{\partial z^{2}} \\
& \frac{\partial P}{\partial y}=\eta \frac{\partial^{2} V}{\partial z^{2}}
\end{aligned}
$$
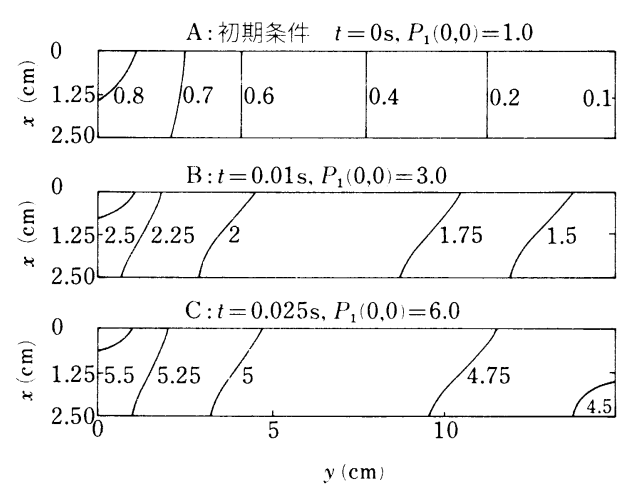

怄 9 保压解析による非定常状態での等压線出力 ( $y$ 軸対称モデル)

ここで, $\bar{U}, \bar{V}$ はおの拉の $x, y$ 方们への平均流速である. 上記の式 $(9)$ 一 (11)から, $2 h$ をキャビティ肉厚として

$$
\begin{aligned}
\frac{\partial \rho}{\partial t} & -\frac{h^{2} \rho}{3 \eta}\left(\frac{\partial^{2} P}{\partial x^{2}}+\frac{\partial^{2} P}{\partial y^{2}}\right) \\
& -\frac{h^{2}}{3 \eta}\left(\frac{\partial P}{\partial x} \frac{\partial \rho}{\partial x}+\frac{\partial P}{\partial y} \frac{\partial \rho}{\partial y}\right)=0
\end{aligned}
$$

が得られ, 式(12)の圧力 $P$ を Spencer-Gilmore 式によ り密度 $\rho$ の関数として記述することにより压維性を考虑 し, Saul'yev 差分法 ${ }^{65)}$ を用いて保压工程をシミュレー トしている。結果例を図 9 に亦す.

この分野では, 今後変形速度の影響や, 周辺固化によ る固液混相状態の記述等をふまえた高精度の解析が期待 される。

\section{5. 収縮・ひけ・配向解析}

成形品の形状精度を考えるうえで重要な点は, 成形品 の冷却収縮に伴う変形の評価法である.保压工程完了後, 樹脂は金型に対し熱を放出しつつ冷却収縮する。この時 点で冷却速度が成形品の部分によつて異なるとき不均一 な収縮によつてひけや反りあるいは残留忍力が発生す る.このうちひけは, リブやボス部を裏に持つ成形品表 


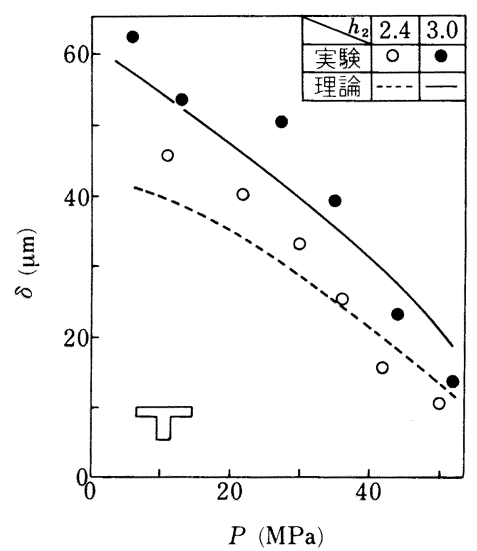

図 10 圧力 $P$ によるひけ量 $\delta$ の変化

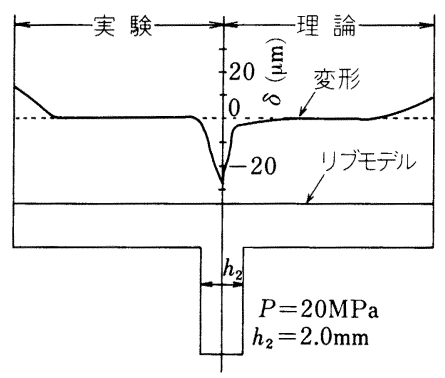

図 11 リブ天板上のひけ解析

面に局部的に生じる凹みを指して言う。ひけの定量化に 対する試みは，丸山ら ${ }^{66)}$ によつて実験検討を主とした 取組が報告されているが, 最近著者らによつて, 非定常 伝熱問題と，樹脂の圧縮性及び相変態を考虑した弾塑性

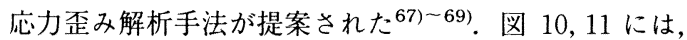
リブ天板上のひけに関し, 成形（保圧）圧 $P$ ・リブ厚さ

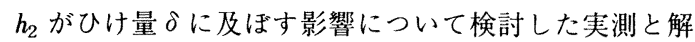
析結果の比較を示す。一方, 冷却固化が周囲において十 分行われた後, 内部の高温樹脂が冷却収縮する場合には, ひけにかわつてボイドと呼ばれる空孔が成形品内に生じ る.ボイドの発生に関しては, TitomanLIO $ら^{70)}$ の研究 がある。 また，金型の冷却のアンバランスや，成形品形 状の熱容量の大幅なかたよりによつて生じる熱応力に関 しては, 有限要素法により熱弾性解析を行つた RIGDAHL $^{71)}$, MENGES ら ${ }^{72)}$ の報告が見られる.

成形品の種々の形状不良に関しては, 上記の熱的要因 によるものの他に, 充填中の流れ場に起因して生じる高 分子の配向によるものも考えられる，高分子の配向が生 じると，材料の機械的性質が異方性を呈することにより 反り等の変形が発生する. BALLMAN ら ${ }^{73)}$ は, 射出成形 過程での分子配向の定量化研究の中で, 固化後の配向パ

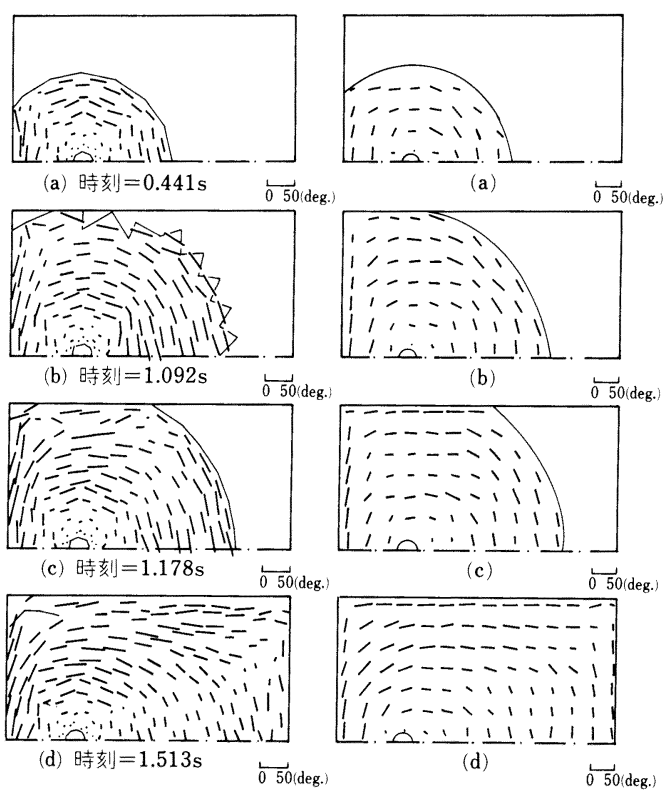

解析から得られたファイバー配 $\begin{aligned} & \text { トレーサーを用いたファイバー } \\ & \text { 向 }\end{aligned}$ 配向実測データ

図 12 ファイバー配向の解析事例

ターンが, せん断力とブラウン運動との相反効果から生 じることを見出した。 また，ガラス繊維等を樹脂に混入 させ，材料強度を向上させることを目的とした FRP (Fiber Reinforced Plastics) に関しても，ガラス瀻維の 配向特性を解析する手法が研究されている74)75). 図 12 に平井ら ${ }^{75)}$ による結果を例示する. 基本的な考え方と して，ガラス㵶維の存在が流体の流れ場に対し影響を及 ほさないという仮定を置き，まず流れ場を単独に解くこ とで求められる速度こう配テンソル，うず度テンソル等 を算出し, これによつて一定半径, 長さを有するモデル 化したファイバー要素が受ける流体力を予測し，ファイ バーの向きを求める ${ }^{76)}$. ファイバーの初期配向を仮定 するかわりに，任意の配向角を設定し，これを統計処理 する手法が多く用いられている.

\section{6. 冷却工程解析}

効率成形の観点に立つと, 充填が完了された樹脂はす みやかに金型から取り出され，次の射出ができる状態に なることが，サイクルタイム短縮を達成するために望ま しい. 従つて, 成形品に対し, 均一かつ敏速に吸熱を可 能とする金型温調溝構造並びにその配置が重要視され る. 金型及び樹脂を含めた伝熱解析は, フーリエの法則 に基づいた熱伝導方程式と対流熱伝達の関係式が用いら れ, その解法も必要に応じて, 差分法, 有限要素法, 境 界要素法等が使い分けられている. 冷却解析単独での研 究報告例 ${ }^{77)-79)}$ は少ない. 図 13 には, 冷却水管配置の 


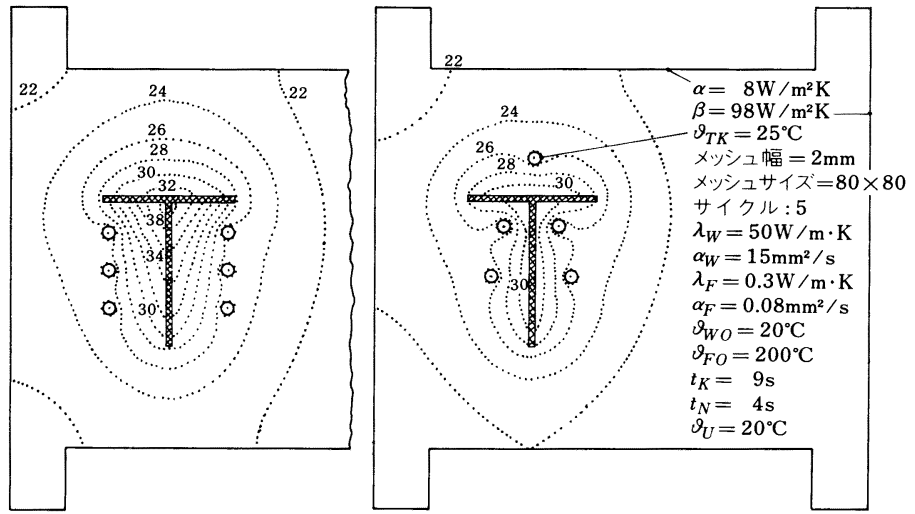

図 13 冷却用の金型温調溝を変 化した時の等温線分布

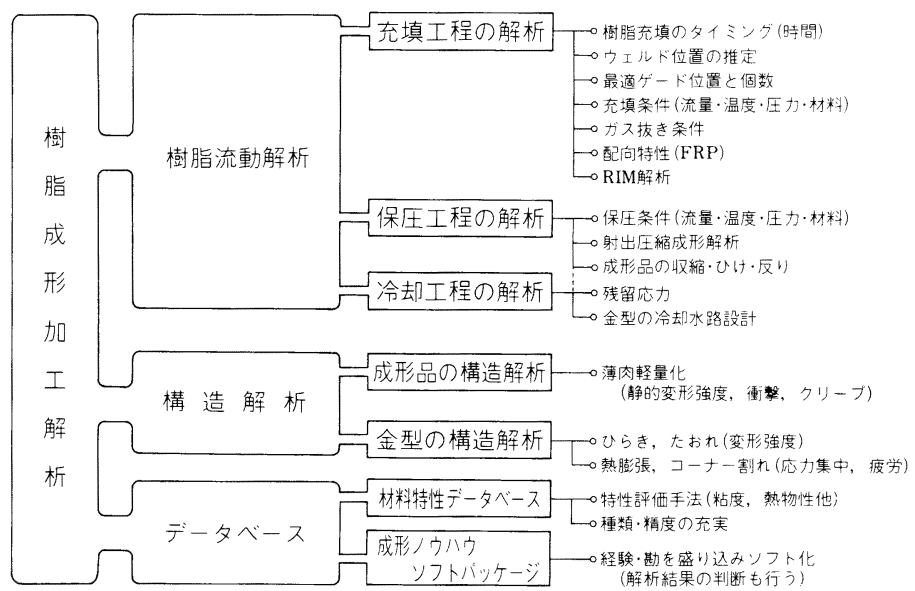

図 14 松下電器産業(株)の「樹脂成形加工解析」システム構想

差による温度分布解析例 ${ }^{79)}$ を示す.

\section{7. ま と め}

以上射出成形にまつわる諸現象に関する研究事例につ いて概説したが, 松下電器産業(株)においても, 樹脂成 形のトータルな解析シミュレーションシステムの構築を 目指して取り組んでいる. 四 14 にシステム構想を示す. 本システムの第 1 の特徵は, 樹脂の射出から成形品取り 出しまでの全プロセスを一貫して解析できる点にある。 昨今の動向から樹脂成形品に対する高精度化，表面性等 外観性重視, 強度向上化への要求が高まる中で, 成形過 程での流れ・熱・応力ひずみの履歴や，時には，金型変 形の影響をも総合的に把握することで，従来以上に厳密 かつ限界を狙つた成形技術の確立が期待できる. 更に, 過去にない新しい成形法に関するアイデアの可能性検討 が机上評価できるようになろう。第 2 の特徴は，独自の 材料評価技術とそれに基づく各種データベースの構築に ある. 先に述べたとおり，材料特性は解析精度を左右す
る最大のポイントと言つても過言ではない，従つて解の 精度を保証するデー夕評価手法の確立と, データベース の充実が重要と言える，更に，第 3 の特徴として，本シ ステムは，射出成形に限らず，他の成形法あるいは樹脂 以外の材料に関する解析をも可能とするよう配慮されて いる点があげられる．具体的には，射出圧縮成形法や反 応射出成形法 (RIM) 等への応用や，ガラス，金属材料 等への適用が考えられる.

以上のシステムは，金型設計製作 $\mathrm{CAD} / \mathrm{CAM}$ システ ムとリンクされてより効率的に運営される．最終的な姿 として, AI (人工知能) を導入し，無人化した金型解析 設計と金型加工の実現も夢では無いと考えられる.

\section{文献}

1 ) C. A. Hieber, $L . S$. Socha, S. F. Shen, $K . K$. Wang and $A$. I. ISAYEv: Polym. Eng. Sci., 23 (1983) 1, p. 20

2 ) $K . K$. Wang, S. F. Shen, C. Cohen, $C . A$. Hieber, T. $H$. KWON and R. C. Ricketson: Progress Report No. 11 (1985), p. 10 [Cornell Injection Molding Project., Cornell Univ. New York] 
3 ) H. W. Cox, C. C. Mentzer and R. C. Custer: Polym. Eng. Sci., 24 (1984) 7, p. 501

4 ) G. Ehrmann, G. Robens and M. H. Wagner: Kunststoffe, 64 (1974), p. 463

5 ) R. KOHLER: Kunststoffe, 68 (1978), p. 367

6 ) F. Ramsteiner: Kunststoffe, 61 (1971), p. 12

7 ) R. J. Crowson, A. J. Scott and $D$. W. Saunders: Polym. Eng. Sci., 21 ( 1981 ) 12, p. 748

8 ) H. A. LoRD: SPE Tech. Pap. Reg. Tec. Conf. (1977), p. 16.1

9 ) R. S. Spencer and G. D. Gilmore: J. Appl. Phys., 21 (1950), p. 523

10) R. S. SPEncer and G. D. Gilmore: J. Colloid Sci., 6 (1951), p. 118

11) B. Maxwell and S. Matsuoka: SPE J., 13 (1957), p. 27

12）大柳 康, 山口章三郎: 日本レオロジー学会誌, 3 (1975) 2, p. 64

13) VDMA, Kenndaten für die Verarbeitung Thermoplastischer Kunstoffe, Thermodynamik, 1 (1979) [Carl Hanser Verlag, München]

14) G. Menges and P. Thienfl: Polym. Eng. Sci., 17 (1977) 10 , p. 758

15) V. H. KarL: Kunststoffe, 68 (1978), p. 247

16) $P$. Thienel, $L$. Schmidt and $V$. Bogatz: Maschinen markt, Würzburg, 84 (1978), p. 1735

17) P. Zoller, P. Bolli, E. Hersche and U. Foppa: Kunststoffe, 66 (.1976), p. 363

18) G. Menges and P. Thienel: Kunststoffe, 65 (1975), p. 696

19) H. Schlichting: Boundary Layer Theory (1979), p. 123 [McGRAW-Hill]

20) G. Titomanl.Io: Polym. Eng. Sci., 22 (1982) 5, p. 324

21) B. Vergnes, P. Saillard and J. F. Agassant: Polym. Eng, Sci., 24 (1984) 12, p. 980

22) A. Y. MaLkin, L. I. SherYSheva and S. G. Kulichikhin: Polym. Eng. Sci., 23 (1983) 15, p. 804

23) M. Grmela: Polym. Eng. Sci., 24 (1984) 9, p. 673

24) M. R. Kamal and P. G. Lafleur: Polym. Eng. Sci., 22 (1982) 17 , p. 1066

25) G. Sornberger, B. Vergnes and J. F. Agassant: Polym. Eng. Sci., 26 (1986) 7, p. 455

26) M. R. Kamal and S. Kenig: Polym. Eng. Sci., 12 (1972) 4, p. 294

27) J. L. White and H. B. DeE: Polym. Eng. Sci., 14 (1974) 3, p. 212

28) G. WÜBKEn, $H$. BANGERT and $L$. SChMidT: Kunststoffe, 74 (1984), p. 46

29) J. L. White: Polym. Eng. Sci., 15 (1975) 1, p. 44

30) J. F. Stevenson, C. A. Hieber, A. Galekoy and $K . K$. Wang: SPE Tech. Pap. Annu. Tech. Conf., 22 (1976), p. 282

31) E. Broyer, C. Gutfinger and $Z$. Tadmor: Trans. Soc. Rheol., 19 (1975) 3, p. 423

32) P. Thienel and G. Menges: Polym. Eng. Sci., 18 (1978) 4, p. 314

33) Y. Kuo and M. R. Kamal: AIChE J., 22 (1976) 4, p. 661

34) G. Williams and H. A. Lord: SPE Tech. Pap. Annu. Tech. Conf., 22 (1976), p. 289

35) H. A. Lord and G. Williams: SPE Tech. Pap. Annu. Tech. Conf., 22 (1976), p. 307

36) L. R. Schmidt: Polym. Eng. Sci., 14 (1974) 11, p. 797

37）堤 健一: PIXEL (図形処理情報センター編), 30 (1985), p. 91

38) M. H. NaITove: Plastics Technology (1984), p. 74
39）後藤輝正, 飯塚邦彦, 宮本雅之, 久保 登, 逢坂正義, 佐原謙一，馬渡恭三郎，西岡郁夫: シャープ技報，34 (1986), p. 63

40）石和正幸, 松沢宇高, 山口 晃, 田村尚久: 古河電工時報, 77 (1986), p. 11

41) 田中豊喜: プラスチックス, 37 (1986) 12, p. 32

42) 高橋秀郎: プラスチックス, 32 (1981) 2, p. 61

43) 後藤輝正: プラスチックス, 37 (1986) 12, p. 45

44) 田中豊喜, 須賀康雄: 日経メカニカル別刷（1985）10月号, p. 144

45) C. G. Gogos and C. F. Huang: Polym. Eng. Sci., 26 (1986) 20, p. 1457

46) $M$. R. Kamal, E. Chu, $P$. G. Lafleur and $M$. E. Ryan: Polym. Eng. Sci., 26 (1986) 3, p. 190

47) $H$. Mavridis, $A$. N. Hrymak and $J$. Vlachopoulos: Polym. Eng. Sci., 26 (1986) 7, p. 449

48) H. BAngert: Kunststoffe, 75 (1985), p. 335

49) J. F. Stevenson: Polym. Eng. Sci., 18 (1978) 7, p. 577

50) A. Moroni, A. Ferrario and A. Casale: Conf. Polym. Rheol. Plast. Process (1976), p. 207

$51) J . F$. Stevenson, $R$. A. Hauptfleish and $C$. A. Hieber: Plastic Engineering, 32 (1976) 12, p. 34

52) M. R. Kamal, Y. Kuo and P. H. Doan: Polym. Eng. Sci., 15 (1975) 12 , p. 863

53) W. L. Krueger and $Z$. Tadmor: Polym. Eng. Sci., 20 (1980), p. 426

54) M. E. Ryan and T. S. Chung: Polym. Eng. Sci., 20 (1980), p. 642

55) S. K. SoH and C. J. Chang: Polym. Eng. Sic., 26 (1986) 12, p. 893

56) 藤井 哲, 辻 俊博: 日機論, 43 (1977), p. 3337

57) N. I. BASOV and I. I. FelipchuK: Heat Trans. Soviet Res., 4 (1972) 2, p. 94

58) D. H. Harry and R. G. Parrett: Polym. Eng. Sci., 10 (1970) 4, p. 209

59) M. R. Kamal and S. Kenig: Polym. Eng. Sci., 12 (1972), p. 294

60) M. R. Kamal and S. Kenig: Polym. Eng. Sci., 12 (1972), p. 302

61) Y. Kuo and M. R. Kamal: Proc. Int. Conf. Polym. Processing (1977), p. 329

62) T. S. Chung and M. E. Ryan: Polym. Eng. Sci., 21 (1981), p. 271

63) T. S. Chung and Y. IDE: J. Appl. Polym. Sci., 28 (1983), p. 2999

64) T. S. Chung: Polym. Eng. Sci., 25 (1985) 11, p. 772

65) V. K. SAuL YEv: Integration of Equation of Parabolic Type by the Method of Nets (1964) [Macmillan, New York]

66）丸山照法, 日部 恒: 高分子論文集, 38 (1981) 4, p. 275

67) 一柳高畤, 中 裕之, 剣持加津衛: 日機論, 53 (1987) 485 , p. 148

68）中 裕之, 一柳高畤, 剣持加津衛: 日機論, 53 (1987) 485, p. 153

69) $H$. Naka, $T$. Ichiyanagi and $K$. Kenmochi: JSME Int. Jour., 30 (1987) 265, p. 1060

70) G. Titomanlio, S. Piccarolo and G. Marrucci: Polym. Eng. Sci., 25 (1985) 2, p. 91

71) M. RigdaHL: Intern. J. Polymetric Mater., 5 (1976), p. 43

72) G. Menges, A. Dierkes, L. Schmidt and E. Winkel: Soc. Plast. Eng. Annu. Tech. Conf., 38 (1980), p. 300

73) R. L. Ballman and H. L. Toor: Modern Plastics, 38 (1960), p. 113 
74) M. Sanou, B. Chung and C. Cohen: Polym. Eng. Sci., 25 (1985) 16, p. 1008

75 ）平井恒夫, 片山伝生, 平井三友, 米田 慎: 材料, 34 (1985), p. 256

76) G. B. JefFery: Proc. Roy. Soc., A102 (1922), p. 161

77) R. F. Host and H. R. OSmers: SPE Tech. Pap. Annu.
Tech. Conf., 24 (1978), p. 77

78) $K . K$. Whang, S. F. Shen, C. Cohen, C. A. Hieber, T. $H$. KWON and R. C. RICKETSON: Progress Report No. 11 (1985), p. 208 [Cornell Injection Molding Project., Cornell Univ. New York]

79) G. WÜBKEn, H. BANGERT and L. SCHMidT: Kunststoffe, 74 (1984), p. 46 